\title{
Recurrent Parotid Gland Acinic Cell Carcinoma
}

National Cancer Institute

\section{Source}

National Cancer Institute. Recurrent Parotid Gland Acinic Cell Carcinoma. NCI Thesaurus.

Code C153571.

The reemergence of parotid gland acinic cell carcinoma after a period of remission. 